\title{
ASSESSING THE USEFULNESS OF A CORE INTRODUCTORY INFORMATION SYSTEMS COURSE IN UNDERGRADUATE CURRICULUM: AN EXPERIMENTAL STUDY
}

\author{
Sushma Mishra, Robert Morris University, mishra@rmu.edu \\ Donna Cellante, Robert Morris University, cellante@rmu.edu \\ Linda Kavanaugh, Robert Morris University, kavanaugh@rmu.edu
}

\begin{abstract}
This paper presents an analysis of the impact of an introductory information systems course concepts on student performance. A survey instrument comprising of 60 items, mapped to program objectives, was developed and conducted in the beginning (pretest) and at the end (posttest) of the semester. The difference in performance of the students from pretest and posttest was calculated for every performance indicator (in aggregate) for the course and each item individually. Significant improvement in performance (more than 50\% from the pretest score) was recorded for a majority of the items. Implications are discussed and future research directions presented.
\end{abstract}

Keywords: Experimental Study, Pretest, Posttest, Introductory Information Systems, Performance Indicator, Course Redesign

\section{INTRODUCTION}

What is the importance of a core introductory information systems course at the college level? Traditional collegelevel courses designed to teach computer literacy are in a state of flux. Today's students have high rates of access to computing technology and computer ownership, leading many educators and decision makers to conclude that students already are computer literate and thus computer literacy courses are not necessary in today's college curriculum. As a result some schools have eliminated the course or only require students to take and pass a basic proficiency test [3]. There is even a school of thought that a core computer course does not even need to be discussed since incoming freshmen have already learned computer competencies at the high school level. Close to 100 percent of students use word processing and utilize the Internet for coursework [10].

However, many students enter college lacking necessary computing skills. While students might be proficient in locating information online through search engines, less is known about the use and application of specific types of software often found in business and industry [13]. How much do students really know about spreadsheets, databases, terminology, tools of the microcomputer, software operating and application system environments, the rapid influx of new mobile technology devices (tablets, smart phones, and e-book readers), and computer ethics and security [10]? The purpose of this study is to determine a student's computer knowledge upon course entry and see if there is a difference in college student's scores as measured by the difference in pretest and posttest scores of students at the end of a college-level introductory computing class. The research questions that this study addresses are:

RQ1: How effectively is a core introductory information systems course meeting program objectives?

RQ2: What are the implications of core information systems course assessment results for undergraduate curricula?

RQ3: What can be done to increase the course effectiveness for non-information systems majors?

The rest of this paper is organized as follows. The next section presents an analysis of research in the area of introductory computer course at the college level as well as definitions of computer literacy and information literacy. The section following the literature review presents the methodology used for this study including data collection and data analysis. The discussions from our findings from our data are presented in the section followed by the conclusions for this study. 


\section{LITERATURE REVIEW}

The review of the literature will define computer literacy and information literacy. It will also discuss the importance of preparedness of incoming freshmen as well as discuss what can be done increase the effectiveness of an introductory computer course at the college level.

\section{Computer Literacy}

In today's society, it is generally accepted that one of the keys to being successful is to be computer literate or to have a certain level of technical competence. There has been much research trying to identify basic computer literacy skills that are needed for all college-level students. Incoming freshmen students complain about having to take an introduction course because they feel like they already "know how" to use computers [4]. "Students often consider themselves proficient in the use of modern technology, but it appears to be the "wrong" type for academic purposes," according to Ratliff (2009). They can chat, Twitter, or social network, but they cannot attach a document to an email. They neglect to use punctuation, rarely use standard formatting, and include slang or acronyms [11]. Morris (2011) sought to explore the relationship between computer self-efficacy and computer proficiency. "Colleges and universities face the daunting task of assessing the computer proficiency of incoming students and training them in the computer skills they will need to be successful in college and beyond" (p. 1). Morris' dissertation concluded that college-age students, although part of the Generation Y, do not possess the computer proficiency skills that are required in the university and college level. Morris (2011) found that computer proficiency scores were low for entering students, which was not expected since these Generation Y (generally students born from the early 80 s to the early 2000 s) students are perceived to have a high computer literacy by definition.

The literature strongly supports the idea that students are coming to college without the skills they need to be considered computer proficient. However, faculty expect students to have intermediate to expert skill levels in the application and Internet domains [14]. Many faculty speculate that students today are more computer literate than their peers several years ago. Prior research suggests that students are not leaving high school with the knowledge necessary to function in either academia or the workplace [14]. High school courses tend to cover computer concepts such as printers, the Internet, hard drives, operating systems, virus protection, and display units [4]. Many high schools today teach their students how to surf the web as well as build web pages [5]. Computer capabilities are essential for success in the business world. Technological advances necessitate learning, maintaining, and upgrading of computer-related knowledge [4]. Computer literacy involves conceptual knowledge related to basic terminology (including social, ethical, legal, and global issues) and skills necessary to perform tasks in word processing, database, spreadsheets, presentation graphics, and basic operating systems functions [4].

\section{Information Literacy}

According to the Association of College and Research Libraries (ACRL, 2000), information literacy is "a set of abilities requiring individuals to 'recognize when information is needed and have the ability to locate, evaluate, and use effectively the needed information." Information technology skills enable an individual to use computers, software applications, databases, and other technologies to achieve a variety of academic, work-related, and personal goals [1]. The International Society for Technology in Education's (ISTE) Standards for learning, teaching, and leading in the digital age set the standard for excellence. The ISTE Standards help educators develop the $21^{\text {st }}$ century skills set forth by the Common Core State Standards, such as problem-solving, critical thinking, creativity, and collaboration skills (ISTE). Digital literacy as defined by Martin (2006) is "an integrating, but not overarching, concept that "focuses upon the digital without limiting itself to computer skills and which comes with little historical baggage" (p. 3). Students today are certainly exposed to and immersed in digital media, but their ability to use information technology to solve common business and real-world problems is frequently over-estimated [9].

\section{Changes Needed for Introductory College Courses}

An introductory course at the college level should address the following content areas: computer hardware, communications technology, operating systems, ethics and security, information literacy, productivity tools, web authoring and publishing, software development, and emerging technologies. The course content should also 
examine economic, social, legal, and ethical issues as well as accessibility. The purpose of the introductory computing course should be to ensure that students achieve an essential understanding of IT infrastructure, learn to use the Web and other network resources, protect their digital data and devices, and become technology users and consumers [12]. Some general goals of the course should be as follows: (1) identify and discuss the four main functions of computer hardware: input, processing, output, and storage; (2) identify and describe major hardware components; (3) identify, describe, and use communications and networking technology; (4) describe the major operating system functions; (5) identify and discuss computer ethics and security issues; (6) demonstrate searching, validation, and evaluation of information; (7) identify, discuss, and use categories of application software; (8) design and create a web pages using XHTML; (9) identify and discuss emerging technology; and (9) understand IT impact on society. By making minor adjustments to the content covered, students will have exposure to all elements of information technology that will be used in their academic, professional, and personal lives. The issues discussed will make living and working in an "information society" easier.

\section{DATA COLLLECTION AND ANALYSIS}

A survey instrument of 60 questions was developed. These questions were mapped to the seven program objectives we have in undergraduate information systems degree. Every performance indicator is represented by 7 or 8 items in the test. The test items were developed with an objective of assessing commonly used knowledge in information systems but ensuring that these topics are covered in the course at some point in time. The three researchers working on this project developed the items. Two of the researchers, who teach the course, gave the test in the first week of the course in fall 2014. These students were informed that this test was assessing their general proficiency in the concepts developed in the course. The students were not informed that they will have the same test for finals. Students were awarded some preliminary points for completing the test in class.

Five sections of INFS 1020 took this test (pretest and posttest). There are total 78 responses from the same. Students were provided with scantrons for the test. The answers were analyzed using DataLink software which pulls the data from scantron reader. This software generates a detailed item analysis report, which was exported in Excel for further analysis. Questions mapped to individual performance indicators were grouped together to generate an average percentage of correct answers. The results of the analysis are presented below.

\section{Results}

The pretest results for the test are as follows.

Table 1: Details of Pretest Results

\begin{tabular}{|l|l|l|l|l|l|}
\hline Total Possible: & 60 & & Exams Graded: & 78 & \\
\hline Highest Score: & 50 & $83.33 \%$ & Average: & 32.4 & $54.06 \%$ \\
\hline Lowest Score: & 9 & $15.00 \%$ & Median: & 34 & $56.67 \%$ \\
\hline
\end{tabular}

Table 2: Performance Item Wise and Performance Indicator Wise

\begin{tabular}{|c|c|c|c|}
\hline Performance Indicators & Items & $\begin{array}{c}\text { Correct } \\
\text { responses }\end{array}$ & $\begin{array}{l}\text { Average } \\
\%\end{array}$ \\
\hline \multirow{8}{*}{$\begin{array}{l}\text { Performance Indicator 1: Establish a firm foundation in } \\
\text { information systems on which students can build successful careers } \\
\text { in an area of expertise of their choice. }\end{array}$} & Question 1 & 70 & \multirow[t]{8}{*}{$78.21 \%$} \\
\hline & Question 2 & 57 & \\
\hline & Question 3 & 64 & \\
\hline & Question 4 & 51 & \\
\hline & Question 5 & 64 & \\
\hline & Question 6 & 54 & \\
\hline & Question 7 & 72 & \\
\hline & Question 8 & 56 & \\
\hline \multirow{2}{*}{$\begin{array}{l}\text { Performance Indicator } 2 \text { : Identify the key components of } \\
\text { information technology equipment. }\end{array}$} & Question 9 & 17 & \multirow[t]{2}{*}{$33.84 \%$} \\
\hline & Question 10 & 14 & \\
\hline
\end{tabular}




\begin{tabular}{|c|c|c|c|}
\hline & Question 11 & 22 & \\
\hline & Question 12 & 17 & \\
\hline & Question 13 & 10 & \\
\hline & Question 14 & 21 & \\
\hline & Question 15 & 47 & \\
\hline & Question 16 & 43 & \\
\hline & Question 17 & 21 & \\
\hline & Question 18 & 52 & \\
\hline \multirow{8}{*}{$\begin{array}{l}\text { Performance Indicator 3: Understand the difference between } \\
\text { computer hardware and software. }\end{array}$} & Question 19 & 64 & \multirow[t]{8}{*}{$57.55 \%$} \\
\hline & Question 20 & 26 & \\
\hline & Question 21 & 19 & \\
\hline & Question 22 & 50 & \\
\hline & Question 23 & 62 & \\
\hline & Question 24 & 18 & \\
\hline & Question 25 & 58 & \\
\hline & Question 26 & 62 & \\
\hline \multirow{8}{*}{$\begin{array}{l}\text { Performance Indicator } 4 \text { : Identify the types and purposes of } \\
\text { computer software whose primary use is in a business environment. }\end{array}$} & Question 27 & 34 & \multirow[t]{8}{*}{$52.74 \%$} \\
\hline & Question 28 & 71 & \\
\hline & Question 29 & 57 & \\
\hline & Question 30 & 28 & \\
\hline & Question 31 & 30 & \\
\hline & Question 32 & 13 & \\
\hline & Question 33 & 50 & \\
\hline & Question 34 & 46 & \\
\hline \multirow{7}{*}{$\begin{array}{l}\text { Performance Indicator 5: Identify the applicability of the life cycle } \\
\text { approach to developing information systems and understand the } \\
\text { activities and expected results of each phase of this process. }\end{array}$} & Question 35 & 52 & \multirow[t]{7}{*}{$48.17 \%$} \\
\hline & Question 36 & 26 & \\
\hline & Question 37 & 68 & \\
\hline & Question 38 & 19 & \\
\hline & Question 39 & 35 & \\
\hline & Question 40 & 14 & \\
\hline & Question 41 & 49 & \\
\hline \multirow{11}{*}{$\begin{array}{l}\text { Performance Indicator 6: Apply microcomputer software and } \\
\text { database software to the solution of problems typically encountered } \\
\text { at the various levels of society and organizations. }\end{array}$} & Question 42 & 46 & \multirow[t]{11}{*}{$44.75 \%$} \\
\hline & Question 43 & 32 & \\
\hline & Question 44 & 4 & \\
\hline & Question 45 & 42 & \\
\hline & Question 46 & 37 & \\
\hline & Question 47 & 42 & \\
\hline & Question 48 & 35 & \\
\hline & Question 49 & 39 & \\
\hline & Question 50 & 37 & \\
\hline & Question 51 & 58 & \\
\hline & Question 52 & 12 & \\
\hline \multirow{8}{*}{$\begin{array}{l}\text { Performance Indicator 7: Understand the encompassing impact of } \\
\text { information technology to every aspect of personal, social and } \\
\text { cultural aspects of life }\end{array}$} & Question 53 & 56 & \multirow[t]{8}{*}{$71 \%$} \\
\hline & Question 54 & 71 & \\
\hline & Question 55 & 73 & \\
\hline & Question 56 & 44 & \\
\hline & Question 57 & 57 & \\
\hline & Question 58 & 25 & \\
\hline & Question 59 & 50 & \\
\hline & Question 60 & 67 & \\
\hline
\end{tabular}

Three out of seven performance indicators have an average of less than $50 \%$ of correct responses. Two indicators have averages in the $50 \mathrm{~s}$ and the other two got an average correct response rate of about 70 percent. The rate of 
correct responses was overall low and this result was not surprising considering this is a required course of all majors here at the university. Another reason for such poor performance could be the lack of any incentive to perform well. Some points were allocated for taking the pretest but it might not be enough for students to carefully work through a 60 -item test in the first week of the class.

The results for posttest is as follows:

Table 3: Details of Posttest Results

\begin{tabular}{|l|l|l|l|l|l|}
\hline Total Possible: & 60 & & Exams Graded: & 78 & \\
\hline Highest Score: & 54 & $90.00 \%$ & Average: & 41.1 & $68.55 \%$ \\
\hline Lowest Score: & 21 & $35.00 \%$ & Median: & 42 & $70.00 \%$ \\
\hline
\end{tabular}

Table 4: Correct responses item wise and performance indicator wise

\begin{tabular}{|c|c|c|c|}
\hline Performance Indicators & Items & $\begin{array}{c}\text { Correct } \\
\text { responses }\end{array}$ & $\begin{array}{c}\text { Average } \\
\%\end{array}$ \\
\hline \multirow{8}{*}{$\begin{array}{l}\text { Performance Indicator 1: Establish a firm foundation in information } \\
\text { systems on which students can build successful careers in an area of } \\
\text { expertise of their choice. }\end{array}$} & Question 1 & 69 & \multirow[t]{8}{*}{85.57} \\
\hline & Question 2 & 62 & \\
\hline & Question 3 & 73 & \\
\hline & Question 4 & 58 & \\
\hline & Question 5 & 66 & \\
\hline & Question 6 & 60 & \\
\hline & Question 7 & 75 & \\
\hline & Question 8 & 71 & \\
\hline \multirow{10}{*}{$\begin{array}{l}\text { Performance Indicator } 2 \text { : Identify the key components of information } \\
\text { technology equipment. }\end{array}$} & Question 9 & 24 & \multirow[t]{10}{*}{58.74} \\
\hline & Question 10 & 30 & \\
\hline & Question 11 & 56 & \\
\hline & Question 12 & 46 & \\
\hline & Question 13 & 8 & \\
\hline & Question 14 & 63 & \\
\hline & Question 15 & 73 & \\
\hline & Question 16 & 52 & \\
\hline & Question 17 & 32 & \\
\hline & Question 18 & 74 & \\
\hline \multirow{8}{*}{$\begin{array}{l}\text { Performance Indicator 3: Understand the difference between computer } \\
\text { hardware and software. }\end{array}$} & Question 19 & 74 & \multirow[t]{8}{*}{75.15} \\
\hline & Question 20 & 59 & \\
\hline & Question 21 & 26 & \\
\hline & Question 22 & 70 & \\
\hline & Question 23 & 68 & \\
\hline & Question 24 & 33 & \\
\hline & Question 25 & 71 & \\
\hline & Question 26 & 68 & \\
\hline \multirow{8}{*}{$\begin{array}{l}\text { Performance Indicator } 4 \text { : Identify the types and purposes of computer } \\
\text { software whose primary use is in a business environment. }\end{array}$} & Question 27 & 26 & \multirow{8}{*}{64.25} \\
\hline & Question 28 & 74 & \\
\hline & Question 29 & 67 & \\
\hline & Question 30 & 44 & \\
\hline & Question 31 & 60 & \\
\hline & Question 32 & 9 & \\
\hline & Question 33 & 60 & \\
\hline & Question 34 & 61 & \\
\hline \multirow{2}{*}{$\begin{array}{l}\text { Performance Indicator 5: Identify the applicability of the life cycle } \\
\text { approach to developing information systems and understand the }\end{array}$} & Question 35 & 56 & \multirow[t]{2}{*}{56.76} \\
\hline & Question 36 & 42 & \\
\hline
\end{tabular}




\begin{tabular}{|c|c|c|c|}
\hline \multirow[t]{5}{*}{ activities and expected results of each phase of this process. } & Question 37 & 66 & \\
\hline & Question 38 & 22 & \\
\hline & Question 39 & 37 & \\
\hline & Question 40 & 31 & \\
\hline & Question 41 & 56 & \\
\hline \multirow{11}{*}{$\begin{array}{l}\text { Performance Indicator 6: Apply microcomputer software and database } \\
\text { software to the solution of problems typically encountered at the } \\
\text { various levels of society and organizations. }\end{array}$} & Question 42 & 62 & \multirow[t]{11}{*}{60.25} \\
\hline & Question 43 & 61 & \\
\hline & Question 44 & 29 & \\
\hline & Question 45 & 33 & \\
\hline & Question 46 & 57 & \\
\hline & Question 47 & 45 & \\
\hline & Question 48 & 54 & \\
\hline & Question 49 & 31 & \\
\hline & Question 50 & 60 & \\
\hline & Question 51 & 71 & \\
\hline & Question 52 & 14 & \\
\hline \multirow{8}{*}{$\begin{array}{l}\text { Performance Indicator 7: Understand the encompassing impact of } \\
\text { information technology to every aspect of personal, social and cultural } \\
\text { aspects of life }\end{array}$} & Question 53 & 58 & \multirow[t]{8}{*}{83.18} \\
\hline & Question 54 & 76 & \\
\hline & Question 55 & 77 & \\
\hline & Question 56 & 51 & \\
\hline & Question 57 & 74 & \\
\hline & Question 58 & 43 & \\
\hline & Question 59 & 66 & \\
\hline & Question 60 & 74 & \\
\hline
\end{tabular}

The average score of correct answers was high on all the performance indicators in the posttest compared to the pretest. Overall, the performance of students improved in the posttest on all program objectives over the pretest, and this is a positive indicator of the impact of the course on students learning outcomes. To get a deeper understanding of the change in performance of students from pretest to posttest, a detailed item-wise analysis was conducted. The item-wise analysis also shows the change in performance of students for every item in terms of percentage. The results are presented in Table 5:

Table 5: With Percentage Changes Per Item

\begin{tabular}{|c|c|c|c|c|c|c|}
\hline \multirow[t]{2}{*}{ Performance Indicators } & \multirow[t]{2}{*}{ Items } & \multicolumn{2}{|c|}{ Pretest } & \multicolumn{2}{|c|}{ Posttest } & \multirow{2}{*}{$\begin{array}{l}\text { Posttest } \\
\text { Average } \\
\%\end{array}$} \\
\hline & & $\begin{array}{l}\text { Correct } \\
\text { response }\end{array}$ & $\begin{array}{l}\text { Average } \\
\%\end{array}$ & $\begin{array}{l}\text { Correct } \\
\text { response }\end{array}$ & $\begin{array}{l}\% \\
\text { Change }\end{array}$ & \\
\hline \multirow{8}{*}{$\begin{array}{l}\text { Performance Indicator 1: } \\
\text { Establish a firm foundation in } \\
\text { information systems on which } \\
\text { students can build successful } \\
\text { careers in an area of expertise of } \\
\text { their choice. }\end{array}$} & Question 1 & 70 & $78.21 \%$ & 69 & $-1.43 \%$ & 85.57 \\
\hline & Question 2 & 57 & & 62 & $8.77 \%$ & \\
\hline & Question 3 & 64 & & 73 & $14.06 \%$ & \\
\hline & Question 4 & 51 & & 58 & $13.73 \%$ & \\
\hline & Question 5 & 64 & & 66 & $3.13 \%$ & \\
\hline & Question 6 & 54 & & 60 & $11.11 \%$ & \\
\hline & Question 7 & 72 & & 75 & $4.17 \%$ & \\
\hline & Question 8 & 56 & & 71 & $26.79 \%$ & \\
\hline \multirow{7}{*}{$\begin{array}{l}\text { Performance Indicator 2: Identify } \\
\text { the key components of } \\
\text { information technology } \\
\text { equipment. }\end{array}$} & Question 9 & 17 & $33.84 \%$ & 24 & $41.18 \%$ & 58.74 \\
\hline & Question 10 & 14 & & 30 & $114.29 \%$ & \\
\hline & Question 11 & 22 & & 56 & $154.55 \%$ & \\
\hline & Question 12 & 17 & & 46 & $170.59 \%$ & \\
\hline & Question 13 & 10 & & 8 & $-20.00 \%$ & \\
\hline & Question 14 & 21 & & 63 & $200.00 \%$ & \\
\hline & Question 15 & 47 & & 73 & $55.32 \%$ & \\
\hline
\end{tabular}




\begin{tabular}{|c|c|c|c|c|c|c|}
\hline & Question 16 & 43 & & 52 & $20.93 \%$ & \\
\hline & Question 17 & 21 & & 32 & $52.38 \%$ & \\
\hline & Question 18 & 52 & & 74 & $42.31 \%$ & \\
\hline \multirow{8}{*}{$\begin{array}{l}\text { Performance Indicator 3: } \\
\text { Understand the difference } \\
\text { between computer hardware and } \\
\text { software. }\end{array}$} & Question 19 & 64 & $57.55 \%$ & 74 & $15.63 \%$ & 75.15 \\
\hline & Question 20 & 26 & & 59 & $126.92 \%$ & \\
\hline & Question 21 & 19 & & 26 & $36.84 \%$ & \\
\hline & Question 22 & 50 & & 70 & $40.00 \%$ & \\
\hline & Question 23 & 62 & & 68 & $9.68 \%$ & \\
\hline & Question 24 & 18 & & 33 & $83.33 \%$ & \\
\hline & Question 25 & 58 & & 71 & $22.41 \%$ & \\
\hline & Question 26 & 62 & & 68 & $9.68 \%$ & \\
\hline \multirow{8}{*}{$\begin{array}{l}\text { Performance Indicator } 4 \text { : Identify } \\
\text { the types and purposes of } \\
\text { computer software whose } \\
\text { primary use is in a business } \\
\text { environment. }\end{array}$} & Question 27 & 34 & $52.74 \%$ & 26 & $-23.53 \%$ & 64.25 \\
\hline & Question 28 & 71 & & 74 & $4.23 \%$ & \\
\hline & Question 29 & 57 & & 67 & $17.54 \%$ & \\
\hline & Question 30 & 28 & & 44 & $57.14 \%$ & \\
\hline & Question 31 & 30 & & 60 & $100.00 \%$ & \\
\hline & Question 32 & 13 & & 9 & $-30.77 \%$ & \\
\hline & Question 33 & 50 & & 60 & $20.00 \%$ & \\
\hline & Question 34 & 46 & & 61 & $32.61 \%$ & \\
\hline \multirow{7}{*}{$\begin{array}{l}\text { Performance Indicator 5: Identify } \\
\text { the applicability of the life cycle } \\
\text { approach to developing } \\
\text { information systems and } \\
\text { understand the activities and } \\
\text { expected results of each phase of } \\
\text { this process. }\end{array}$} & Question 35 & 52 & $48.17 \%$ & 56 & $7.69 \%$ & 56.76 \\
\hline & Question 36 & 26 & & 42 & $61.54 \%$ & \\
\hline & Question 37 & 68 & & 66 & $-2.94 \%$ & \\
\hline & Question 38 & 19 & & 22 & $15.79 \%$ & \\
\hline & Question 39 & 35 & & 37 & $5.71 \%$ & \\
\hline & Question 40 & 14 & & 31 & $121.43 \%$ & \\
\hline & Question 41 & 49 & & 56 & $14.29 \%$ & \\
\hline \multirow{11}{*}{$\begin{array}{l}\text { Performance Indicator 6: Apply } \\
\text { microcomputer software and } \\
\text { database software to the solution } \\
\text { of problems typically } \\
\text { encountered at the various levels } \\
\text { of society and organizations. }\end{array}$} & Question 42 & 46 & $44.75 \%$ & 62 & $34.78 \%$ & 60.25 \\
\hline & Question 43 & 32 & & 61 & $90.63 \%$ & \\
\hline & Question 44 & 4 & & 29 & $625.00 \%$ & \\
\hline & Question 45 & 42 & & 33 & $-21.43 \%$ & \\
\hline & Question 46 & 37 & & 57 & $54.05 \%$ & \\
\hline & Question 47 & 42 & & 45 & $7.14 \%$ & \\
\hline & Question 48 & 35 & & 54 & $54.29 \%$ & \\
\hline & Question 49 & 39 & & 31 & $-20.51 \%$ & \\
\hline & Question 50 & 37 & & 60 & $62.16 \%$ & \\
\hline & Question 51 & 58 & & 71 & $22.41 \%$ & \\
\hline & Question 52 & 12 & & 14 & $16.67 \%$ & \\
\hline \multirow{8}{*}{$\begin{array}{l}\text { Performance Indicator } 7 \text { : } \\
\text { Understand the encompassing } \\
\text { impact of information technology } \\
\text { to every aspect of personal, social } \\
\text { and cultural aspects of life }\end{array}$} & Question 53 & 56 & $71 \%$ & 58 & $3.57 \%$ & 83.18 \\
\hline & Question 54 & 71 & & 76 & $7.04 \%$ & \\
\hline & Question 55 & 73 & & 77 & $5.48 \%$ & \\
\hline & Question 56 & 44 & & 51 & $15.91 \%$ & \\
\hline & Question 57 & 57 & & 74 & $29.82 \%$ & \\
\hline & Question 58 & 25 & & 43 & $72.00 \%$ & \\
\hline & Question 59 & 50 & & 66 & $32.00 \%$ & \\
\hline & Question 60 & 67 & & 74 & $10.45 \%$ & \\
\hline
\end{tabular}

The range of the variation of student performance on the test items, from pretest to posttest, is wide. To better understand the change in percentage of correct responses from pretest to posttest, categories of question items were constructed and frequency for the each category was calculated as presented below in Table 6 . The change in percentages of the correct answers was calibrated into categories showing the progression of the improvement from low to high. These five categories were developed conceptually by the researchers. The category "Minimal" contains items showing less than $10 \%$ change from pretest score to posttest score (including negatives). Items that 
changed in the range of $10 \%$ to less than $25 \%$, from pretest to posttest, were categorized in one group labeled "Average". The category "Good" contains items showing a change 25\% to less than 50\%, from pretest to posttest scores. The group that contains items which changed in the range of $50 \%$ to less than $100 \%$, from pretest to posttest, is labeled "Excellent". The last group, containing items registering a change of more than 100\%, from pretest to posttest score, is labeled "Outstanding". The frequencies of the items in the respective groups in presented below in Table 6.

Table 6: Categories of Change in Student Performance, from Pretest to Posttest, with Frequencies

\begin{tabular}{|l|c|}
\hline \multicolumn{1}{|c|}{ Categories of Items } & Frequency \\
\hline Items that changed less than $10 \%$ from pretest to posttest: Minimal & 19 \\
\hline $\begin{array}{l}\text { Items that changed in the range of } 10 \% \text { to less than } 25 \% \text {,from pretest to } \\
\text { posttest: Average }\end{array}$ & 9 \\
\hline $\begin{array}{l}\text { Items that changed in the range of } 25 \% \text { to less than } 50 \% \text {,from pretest to } \\
\text { posttest: Good }\end{array}$ & 10 \\
\hline $\begin{array}{l}\text { Items that changed in the range of } 50 \% \text { to less than } 100 \% \text {,from pretest to } \\
\text { posttest: } \text { Excellent }\end{array}$ & 8 \\
\hline Items that changed more than $100 \%$,from pretest to posttest: Outstanding & \\
\hline
\end{tabular}

The above table suggests a wide range of change in the performance of students based their scores in pretest versus posttest. The "minimal" category has 19 items, which is around $31.6 \%$ of the total items on the test. There were 7 items in this category that showed a negative change in percentage, which means the score of the students was better in pretest than the posttest. This warranted an analysis of the items per se. The researchers found that out of these seven items, three could have been worded less ambiguously and two items had options that suggest more than one right answer. The remaining two items did not suggest any obvious reason for a negative growth in score. There was a growth in performance of students in the range of $25 \%$ to less than $50 \%$, from pretest to posttest, for 9 items on the test. This suggests that $15 \%$ of the total test items showed a steady progression in performance of the students. Nearly half of the items (45\%) showed a growth in performance of students in the range of $25 \%$ to more than $100 \%$, from pretest to posttest scores. This is an impressive growth in performance of students considering this is a service course for all undergraduates irrespective of their majors. Eight items (nearly 15\%) out of the total items show outstanding growth in performance from pretest to posttest of more than $100 \%$. This is a clear indication of the increased learning and better understanding of concepts for the students.

\section{DISCUSSSION}

The results suggest the introductory information systems course is quite effective in meeting program objectives. The posttest results for three out of seven objectives are above $70 \%$ average correct response rate, which is impressive. Each program objective has registered a positive growth, from pretest to posttest scores, in student performance. Students are willing to learn and improve upon concepts in technology, even if it is not their major of choice. Considering that half the items on the tests showed a growth of more than $50 \%$ in student performance, from pretest to posttest, it can be inferred that the students are learning very important technological concepts and performing well. Some items on the tests did not show positive improvements, from pretest to posttest, but these items had formulation and execution issues rather than content specific hurdles.

The performance does improve in many areas but some areas such as systems development, MS Access and databases did not register much growth. This is not a surprising finding. Research literature in this area suggests that introductory level fundamental information technology courses are not perceived as useful by the students as intended to be. The content of the course closely follows any introductory IS level course and includes topics such as hardware, software, telecommunication, networking, security, databases, systems development and tools, such as Excel and Access. The students perceive some topics to be more useful to them than others. Some of the reasons for dissatisfaction could be perceived lack of relevance of the content and lack of depth in skills taught [2]. It would be interesting to see what topics are perceived to be more important to the students and why. This inquiry might lead into adapting the course content/style in a way that is considered more applicable and usable by students today.

Table 7: Summary of Findings/Implications of the Study 


\begin{tabular}{|c|c|}
\hline Research Questions & Findings/Implications \\
\hline $\begin{array}{l}\text { RQ1: How effectively is a core } \\
\text { introductory information } \\
\text { systems course meeting program } \\
\text { objective? }\end{array}$ & $\begin{array}{l}\text { - Positive growth in performance of students on all the seven program } \\
\text { objective in the posttest results } \\
\text { - About half of the items on the test showed a growth of more than } 50 \% \text { in } \\
\text { performance of the students in posttest }\end{array}$ \\
\hline $\begin{array}{l}\text { RQ2: What are the implications } \\
\text { of core information systems } \\
\text { course assessment results for } \\
\text { undergraduate curricula? }\end{array}$ & $\begin{array}{l}\text { - Students with different majors have the ability to learn and perform well in } \\
\text { introductory level technology course } \\
\text { - The course in its current form requires modifications to enhance the } \\
\text { learning experience of these students }\end{array}$ \\
\hline $\begin{array}{l}\text { RQ3: What can be done to } \\
\text { increase the course effectiveness } \\
\text { for non-information systems } \\
\text { majors? }\end{array}$ & $\begin{array}{l}\text { - The course needs to be redesigned addressing the needs to the students in a } \\
\text { bounded manner } \\
\text { - Establish the importance of the concepts of technology in a non-technology } \\
\text { career }\end{array}$ \\
\hline
\end{tabular}

Introduction to information systems is an important course for IS majors as well as non-majors. In the current information-centric economy, it is critical that every college graduate has pertinent technology skills to meet their day-to-day work requirements in a career of their choice. The importance of such a course is well established in research literature. The question now is "what" to teach and "how" to teach in a way that excites IS majors and nonmajors of this current generation of college freshmen. There are major course design implications that have emerged in this study. The students find certain concepts irrelevant, boring or difficult compared to some others. This leads to a question which we as educators have been trying to answer for a while; i.e., "what" should be taught in this course? It seems that an attempt to package all the major information systems concepts together in one course, along with practical usage of Excel and MS Access, overwhelms our students. We need to find a way to focus on topics that we think are most important and hence address the need to learn technology in a channeled and bounded manner.

\section{CONCLUSIONS}

Based on our findings, this study clearly suggests that entering freshmen have not learned all they need to know about computer topics at the high school level in order to be successful in academia and the workplace. The previous section answered the research questions and showed that an introductory course is quite effective overall in delivering basic concepts. However, the question of "what" and "how" to teach these concepts requires further inquiry

\section{REFERENCES}

1. Association of College \& Research Libraries. (January 2000). Information literacy competency standards for higher education. ACRL Standards Committee.

2. Aytes, K. (2004). Adding value to the core business curriculum: Innovative use of IS courses. AMCIS 2004 Proceedings. Paper 25. Available: http://aisel.aisnet.org/amcis2004/25

3. Ciampa, M. (2013). Student perceived importance and correlations of selected computer literacy course topics. Journal of Instructional Pedagogies, p. 1. Available: www.aabri.com/manuscripts/131490.pdf

4. Hindi, N., Miller, D., \& Wenger, J. (2014). Computer literacy: Implications for teaching a college-level course. Journal of Information Systems Education, 13(2), p. 143-152.

5. Holmes, M., Switzer, S., \& Csapo, N. (2002). A comparison of the computer skills of business students versus those incoming freshmen. International Association of Computer Information Systems, p. 275-281. Available: from iacis.org/iis/2002/HolmesSwitzerCsapo.pdf

6. ISTE Position Statement on the Common Core State Standards. (2014). International Society for Technology in Education. Available: http://www.iste.org/standards/common-core

7. Martin, A. (2006). Literacies for the digital age. In A. Martin \& D. Madigan (Eds.), Digital literacies for learning. London: Facet Publishing, p. 3-25.

8. Morris, K. (2011). College and the digital generation: Assessing and training students for the technological demands of college by exploring relationships between computer self-efficacy and computer proficiency. In M. Parker. (Doctoral candidate, May 2015). Role of computer competency in student's success in blended learning 
instruction: A cross sectional case study between military/veteran, traditional and non-traditional students (Doctoral dissertation). Robert Morris University, Pennsylvania.

9. Murray, M. \& Perez, J. (2014). Unraveling the digital literacy paradox: How higher education fails at the fourth literacy. Issues in Informing Science and Information Technology, 11, p. 85-100. Available: http://iisit.org/Vol11/IISITV11p085-100 Murray0507.pdf

10. Nataraj, S. (2014). The need for an introductory computer literacy course at the university level. International Journal of Business Management and Economic Research, 5(4), p. 71-73.

11. Ratliff, V. (December 2009). Are college students prepared for a technology-rich learning environment? MERLOT Journal of Online Learning and Teaching, 5(4), p. 698-702.

12. Sanghera, K. (2013). IT103: Introduction to Computing, Course syllabus. George Mason University, The Department of Applied Information Technology, Fairfax, VA.

13. Spicer-Sutton, J. R. (2013). Self-assessment and student improvement in an introductory computer course at the community college-level. Electronic Theses and Dissertations, Paper 133;//dc.etsu.edu/etd/1133

14. Stone, J., Hoffman, M., Madigan, E., \& Vance, D. (June 2006). Technology skills of incoming freshmen: Are first-year students prepared? Consortium for Computing Sciences in College. http:www.academic.edu/772695/Technology-skills-of-incoming-f... 